\title{
sciendo
}

\section{The fintech ecosystem in Romania}

\author{
Ion-Costel-Marius BĂLȚOI \\ Bucharest University of Economic Studies, Bucharest, Romania \\ marius.baltoi@ie.ase.ro
}

\begin{abstract}
Increasing the rate of use of mobile devices and the Internet, as well as the development of new technologies, is rapidly impacting the financial market and electronic payments, in particular. Thus, Romania has become one of the countries in which the users have a lot of variants for managing individual funds, purchasing goods and services through digital channels. Also, we can say that Romania represents at regional level one of the countries with growth potential both due to the size of the market, as well as the innovation potential of entrepreneurs and big companies / financial institutions. The purpose of the present research is to carry out an analysis on electronic payments in Romania, of the way in which fintech applications develop and of the environment in which they operate. To this end, a qualitative research will be carried out by studying the available scientific resources that address the topic of fintech applications, specialized articles that address the topic of electronic payments, as well as the features that fintech applications offer to users. The first part will present an introduction and a statistical analysis of the data regarding fintech applications and market dimensions. Next, the article proposes for research the fintech ecosystem in Romania from the point of view of the Romanian fintech services and a SWOT analysis of the Romanian market will be performed.
\end{abstract}

Keywords: fintech applications, electronic payments, mobile applications, capital market, money transfer.

\section{Introduction}

The recent technological evolution has impacted all the economic fields, bringing a lot of advantages to the individual users, as well as to the companies involved. Thus, the financial field and the way the payments are made have evolved, everything becoming simpler, faster, cheaper and secure. The increasingly visible involvement of technology companies in the financial field has given rise to fintech companies. Thus, the term „Fintech” (or financial technology) describes companies that provide financial services to individual users or businesses through the use of software and modern technologies.

Currently, fintech companies and traditional financial institutions operate on the same market, respectively on the financial services market. From an economic point of view and considering the rules of the market, we can see that they are in direct competition, the target being to attract as many customers on their channels and their loyalty, selling services and solutions to customers. Most of the time, you can see even a collaboration between fintech companies and classic banks in offering competitive financial products and quality services (Hadad \& Bratianu, 2019; Moraru \& Duhnea, 2018; Nguyen \& Rozsa, 2019). Thus, banks are forced to be agile, open to innovation and invest in technology.

In terms of speed of innovation, adaptation to new market conditions and customer requirements, fintech companies have a visible advantage due to the specific agility of the technology companies and the reduced regulations compared to the regulations that a bank must comply with. Thus, starting with solutions for money transfer, investments, payment technologies, digital wallets, virtual currencies, loans and financing solutions, fintech companies offer services through technology and at low costs.

In Romania, the services of the fintech companies were quickly adopted by the users. Thus, one of the factors that contributed to the adoption of fintech services was good internet 
connectivity. Figure 1 presents statistics regarding Internet users in Romania; we note that in 2019, $77 \%$ of the total population used the Internet network, of which $69 \%$ used mobile devices to access the Internet. In absolute size, 15.04 million inhabitants are active users of the Internet, of which 13.4 million use mobile devices.

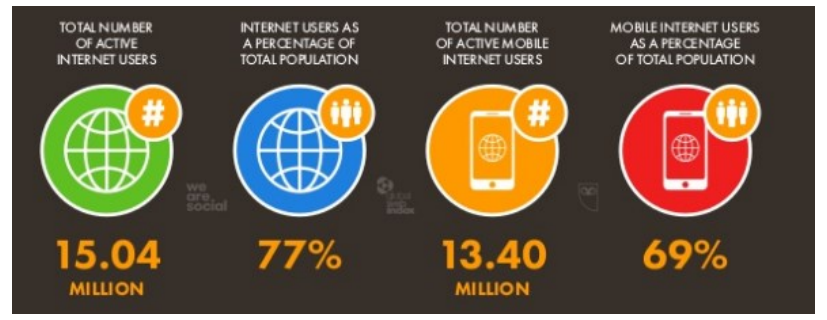

PICBE | 274

Figure 1. Statistics regarding Internet users in Romania

Source: www.datareportal.com.

Analyzing Figure 2, we can see that at the level of Romania, in 2019, 10.47 million people have used electronic payment services, and the trend is increasing in the coming years. Thus, in 2023, in Romania there will be 11.2 million active users.

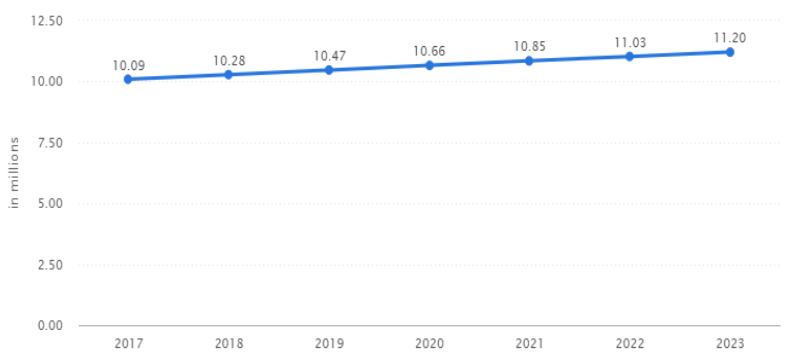

Figure 2. Trends in economic payments

Source: www.statista.com.

Figure 3 shows the financial services offered by fintech companies, grouped into 4 categories: digital payments (at POS or electronic commerce devices), personal finance (investment funds, overseas transfers), alternative loans (Crowdlending - for business or Marketplace Lending - for individual consumers) and alternative financing (crowdinvesting and crowdfunding). As can be seen in figure 3, the population of Romania uses to a large extent the electronic payment services. The other categories of services are too little known to the general public, with few users choosing to manage their finances through fintech services. The services of Alternative lending and alternative financing are very little known in Romania, most of the clients preferring to resort to the financing services offered by the classic financial institutions.

In terms of electronic payment services, Figure 3 shows a constant increase of their volume of almost 0.5 billion dollars annually, in 2023 to reach 5.361 billion dollars.

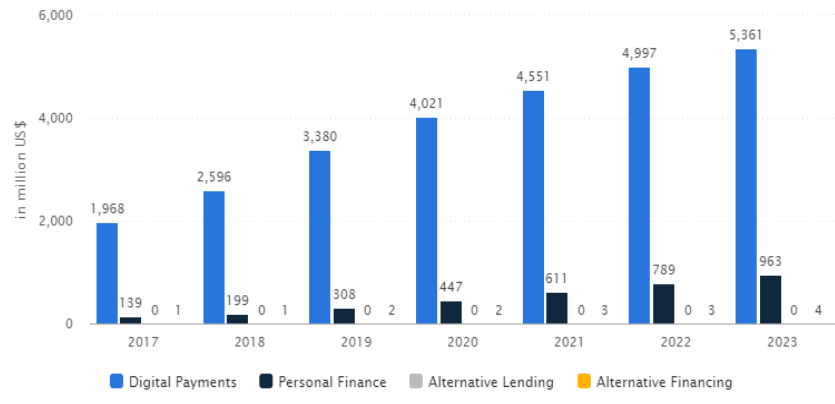

Figure 3. Financial services statistics

Source: www.statista.com. 
The paper (Mihail, 2018) proposes a new way of distributing fintech services, based on the report issued by the European Banking Authority in 2017 (European Banking Authority, 2017). In this sense, fintech services are divided into 4 categories:

- Payment services: mobile wallets, peer-to-peer transfers (P2P), digital currency exchange platforms, virtual currencies, invoice payment services

- Personal finance management services: risk analysis, crowdfunding, peer-to-peer financing, online banking and mobile banking

- Investment services and investment management: trading services through online platforms, copy-trading, e-trading, robotic consulting

- Other activities: customer knowledge services (eg financial background)

Also, the report presented by the European Banking Authority analyzes the financial innovations applied by the companies in the field. Thus, we distribute information online and on mobile devices, electronic financial management tools, roboadvices, big data analytics, data aggregation services, biometric technology, digital client authentication, virtual currencies or cloud computing.

\section{Fintech market in Romania}

According to the Digital Evolution: Connected Consumer Monitor study conducted in November 2018, 16\% of Internet users in Romania currently use financial services offered by fintech companies. Among the reasons presented by users in the survey, the most important is trust (40\%), followed by the lack of bureaucracy (34\%), instant transfers of money to various accounts (30\%), advantageous exchange rate $(29 \%)$, possibility withdrawal of money from any atm without commission (28\%), secure systems $(27 \%)$. Also, among the reasons why many people still do not use alternative financial services are lack of information $(32 \%)$, fear due to lack of use information $(21 \%)$ or satisfaction with the current bank (21\%) (Insider, 2019). Also, among the most popular fintech applications are Telekom Banking, Orange Money, Revolut, Monese, iCard.

According to the report made by Raiffeisen Bank International in Romania at the end of 2018, of the 49 fintech companies existing on the local market, 18 (37\%) offered retail banking services, $9(18 \%)$ offered technology services, $8(6 \%)$ SME Banking services, the rest of the fintech companies being active in the areas of insurance, corporate banking, capital markets, wealth management and support (Raiffeisen Bank International, 2018). The report also highlights the fact that $47 \%$ of the total population use digital payment services and $12 \%$ of the population pay the bills online.

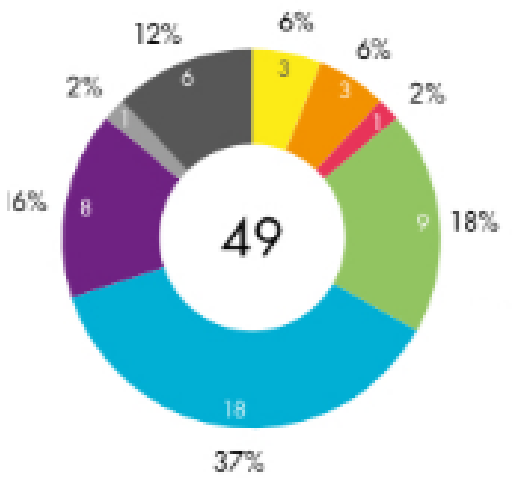

Figure 4. Type of fintech services in Romania 


\section{Literature review}

Paper (Micu \& Micu, 2016) approaches a series of fintech innovations proposed by financial service providers on the Bucharest Stock Exchange, under the direct supervision of the regulatory authorities. Thus, fintech innovations on the capital market can be grouped into 2 categories, one concerning the operations of financial service providers, and the second category refers to the interaction of financial service providers with their clients. In the first category we can include the integration of supplier systems with those of institutions such as the Stock Exchange, the Central Depository and through the regulatory framework proposed by the Financial Supervisory Authority, regarding reporting and confidentiality.

The study in paper (Duma \& Gligor, 2018) presents the perception and behavior of the young people from the $\mathrm{Z}$ generation (or the Gen Tech generation) towards the innovations that the fintechs bring to the market, with an emphasis on online payments and virtual currencies. Thus, we can consider that the young people from $\mathrm{Z}$ generation approach with openness and curiosity the new financial services proposed by fintechs, are open to the adoption of innovation.

Article (Manta, 2018) presents the dilemma that regulatory authorities may have. Thus, they have a choice between a clear regulation, based on rules that establish the rights and obligations of the institutions involved in fintech services (often they can be expensive and can represent a barrier to innovation for startups and the creation of new jobs) or a principles-based regulation (it has the advantage of being more flexible, but implies some uncertainty in the market regarding the confidentiality and data security of those using fintech services).

Paper (Kavuri \& Milne, 2019) addresses 7 major changes that fintech services bring to society. The 7 major changes found in the paper are the result of debates in the academic environment and they are proposed for further research. Among these changes, we can list the change in the way financial services are organized, the emergence of new forms of financial intermediation (alternative financing: loan-based and equity-based crowdfunding), the change in the way payments are made and the transition to a cashless society, the approach to vulnerable clients from developed areas and from developing countries, involving artificial intelligence and machine learning in fund management, the relationship between financial technologies and financial regulations, confidentiality and security of processed data.

Article (Business Review, 2019) provides an overview of the market for fintech companies operating in Europe, based on the Deloitte report from 2017. Also, the authors offer a series of tips that entrepreneurs from Poland and Romania must follow to fully benefit from the technological evolution and the impact it has in the area of financial services.

\section{Methodology}

In this paper a qualitative research is carried out. In this sense, the collection of information will be done by analyzing the scientific resources that approach the proposed topic, especially scientific articles published on specialized scientific networks (for example, ResearchGate) or articles published in various journals. Also, in documenting this article I will use a series of reports issued by various institutions (for example, the European Banking Authority Raiffeisen Bank International, Deloitte, etc.) and analyzing various phenomena and trends within the field of study, as well as a series of online resources that present the context in which fintech services are currently available and a series of current statistics collected from reports or specialized sites on data analysis.

\section{The Romanian fintech ecosystem}


The recent period on the fintech market in Romania has meant a marked increase based on the adoption of either external services (Revolut, Paysera, Transferwise, Aforti Exchange, for example) or on the development of local startups (Volt, Pago, FintechOS, de example).

The main advantage of fintech startups is the agility, the speed with which they innovate in the market and the way they adapt to new changes compared to financial institutions. We also note a number of advantages as a human resource, its support through flexible working programs, learning opportunities, rapid decision-making processes (Ensight, 2019).

The evolution of fintech companies in Romania was positively influenced by the European PSD2 (Payment Services Directive). The PSD2 directive eliminated the monopoly of the financial institutions on the clients information, forcing them to give access to the financial information to third parties, respecting the same safety and security requirements. Through this directive, fintech companies have the opportunity to develop and innovate on the market, implicitly transforming the financial system through technology (Baltoi, 2019).

The concept of OpenBanking was developed in Romania especially after the application of the European PSD2 directive. Until then, banks were showing a certain rigidity in transmitting financial information to clients. Open banking allows the interconnection of systems and data from different institutions to be used by clients, financial or regulatory institutions, third party service providers. Among its benefits, we can find the ease of electronic payments (payments are made directly by the bank), consumer support in finding the best offer of financial goods and services, improved security or proper functioning on mobile devices.

\section{Analysis of the functionalities of the Romanian fintech services}

In the recent period, the favorable economic context has encouraged the creation and development of new fintech services. Thus, on the Romanian market appeared and developed specialized startups on a certain range of fintech services. We can list Pago, Volt, Beez, PayByFace for digital payments and wallets, Cash Control App for personal finance management, iFactor or Human Finance for lending and crowdfunding, FintechOS for financial infrastructure, StockBerry or Optimus for investment and wealth management (Future Banking, 2020).

\section{Table 1. Romanian fintech startups}

\begin{tabular}{|l|l|l|}
\hline Name & Description & Year \\
\hline Pago & $\begin{array}{l}\text { Pago facilitates the payment of local bills, taxes and taxes, donations and } \\
\text { insurance, as well as the instant transfer of money. For each operation performed } \\
\text { through the application, customers are rewarded and can use the points for } \\
\text { subsequent transactions. }\end{array}$ & 2016 \\
\hline Volt & $\begin{array}{l}\text { Volt offers the possibility of instant transfer of money between various cards } \\
\text { issued by banks in Romania. Moreover, the transfer is fast, secure and simple, in } \\
\text { a few minutes the transfer is made based on the data saved in the application. }\end{array}$ & 2017 \\
\hline Beez & $\begin{array}{l}\text { Beez is an alternative financial service that works on the "buy now, pay later" } \\
\text { model and improves credit card shopping experience. Thus, the buyer has the } \\
\text { possibility to buy a good through the application and to pay its value at the } \\
\text { guaranteed price, or to be credited without any commission or deposit. }\end{array}$ & 2018 \\
\hline PayByFace & $\begin{array}{l}\text { PayByFace is a secure payment system for faster and more comfortable shopping. } \\
\text { Using biometric authentication, the buyer is quickly recognized and the payment } \\
\text { is made in seconds. }\end{array}$ & 2019 \\
\hline CashControl & $\begin{array}{l}\text { CashControl is a system by which users can monitor their expenses, incomes, } \\
\text { payment of loans, payment of invoices and can make a future financial health } \\
\text { estimate. The system is available both on the web and through Android or iOS } \\
\text { mobile applications. }\end{array}$ & 2011 \\
\hline iFactor & $\begin{array}{l}\text { iFactor is an intermediary online platform between small and medium-sized } \\
\text { companies that need financing and banks / investors who are willing to give them }\end{array}$ & 2016 \\
\hline
\end{tabular}




\begin{tabular}{|l|l|l|}
\hline & $\begin{array}{l}\text { liquidity. The financing process runs efficiently, offers risk analysis services, anti- } \\
\text { fraud systems and payments. }\end{array}$ & \\
\hline $\begin{array}{l}\text { Human } \\
\text { Finance }\end{array}$ & $\begin{array}{l}\text { Human Finance is a platform that supports entrepreneurs in order to accumulate } \\
\text { knowledge and financing capabilities of the business. Also, the platform is useful } \\
\text { by attracting investors (for example, business angels) or creditors. }\end{array}$ & 2018 \\
\hline FintechOS & $\begin{array}{l}\text { FintechOs is a platform that allows companies to easily integrate artificial } \\
\text { intelligence with various data processing modules in a fast way and at competitive } \\
\text { costs. The platform also allows companies to manage business growth, increase } \\
\text { customer retention and accelerate business digitization. }\end{array}$ & 2017 \\
\hline StockBerry & $\begin{array}{l}\text { StockBerry is a mobile application used on the capital market to monitor the } \\
\text { evolution of indicators. One of the most important features is the monitoring of } \\
\text { investor sentiment based on artificial intelligence. }\end{array}$ & 2017 \\
\hline Optimus & $\begin{array}{l}\text { Optimus is an automated robo adviser platform for retail investors for wealth } \\
\text { management purposes. This offers users transparency and low costs through the } \\
\text { use of technology. }\end{array}$ & 2018 \\
\hline
\end{tabular}

PICBE | 278

The solutions analyzed in Table 1 are only part of the fintech services existing on the Romanian market and started by Romanian entrepreneurs. We notice a large presence of startups in the electronic payment market due to the potential of the volume of payments, but also to the increasing number of users. Also, we can notice startups with growth potential in the other fintech areas analyzed; some of them have been developed in other markets, being able to list Pago on the market in Croatia, Italy or Poland, Beez in the UK, FintechOS in the UK, Netherlands, Austria, Denmark, StockBerry on various markets in the global area, etc.

\section{SWOT analysis of Romania}

At the level of the fintech industry, Romania has a number of strengths that benefit it in the competition with neighboring countries, respectively Western European countries. Thus, among the major advantages we can list the highly skilled and cheap labor force, favorable macroeconomic context, the low level of taxation. On the other hand, there are some problems that require serious analysis and corrective measures from the responsible parties (Deloitte, 2017).

Regarding Romania's strengths, the high economic growth in recent years and the country's demographics are 2 of the points that make it attractive for attracting fintech companies to the local market / developing local fintechs. Also, highly skilled IT workforce with high professional skills and cheap compared to developed countries in Western Europe can attract international fintech companies to open development centers / services on the local market. An important role in this development of the IT sector has a high degree of adoption of new technologies and their integration both in new software products and in existing software products. Also, we can notice the high level of foreign investments in Romania due to the high degree of confidence of investors in the growth potential of the market. In parallel, the central state administration encourages the development of local startups in various economic fields, the technology and innovation part benefiting from substantial funds from the state budget.

Romania's weaknesses concern both the economic and social context, as well as aspects related to the education and behavior of people in society, aspects that can be corrected in time, with the involvement of the state. In terms of people's behavior, we can list a high level of corruption in the state administration and a high level of untaxed economic operations in the economy; thus, the state does not collect significant amounts of money which it can then reinvest in improving the business environment or other important sectors. Also, the lack of digitalization of the administration leads to major labor costs, bureaucracy, time delays or possible errors due to the human factor. The low incomes of the population (the average gross salary in the economy is 1550 euros, among the lowest in the European Union), which leads to a low saving rate of the 
country's population. Another weak point is the fact that only $77 \%$ of the country's population uses the Internet; this aspect may be due to demography (advanced age of the population, isolated households located far from localities, etc.).

Table 2. Strengths and weaknesses

\begin{tabular}{|l|l|}
\hline Strengths & Weaknesses \\
\hline High economic growth (over 4\% in 2019) & High level of non-fiscal operations in the economy \\
\hline $\begin{array}{l}\text { Market with high growth potential (the second largest } \\
\text { population in Central and Eastern Europe) }\end{array}$ & $\begin{array}{l}\text { Demographic distribution of inhabitants (about half } \\
\text { of inhabitants live in rural areas) }\end{array}$ \\
\hline Software development centers and skilled workforce in IT & Low level of internet users (77\%) \\
\hline $\begin{array}{l}\text { Low cost of labor compared to the EU average (27.4 euros } \\
\text { at EU level and 6.9 euros / hour in Romania) (Eurostat, } \\
\text { 2019) }\end{array}$ & $\begin{array}{l}\text { Low investments in the digitization of public } \\
\text { services (implementation of electronic payment } \\
\text { services) }\end{array}$ \\
\hline The high level of foreign investments & Low level of saving of population \\
\hline Financing programs for startups & The high level of corruption \\
\hline $\begin{array}{l}\text { High degree of adoption of new software development } \\
\text { technologies }\end{array}$ & \\
\hline
\end{tabular}

Regarding the opportunities that fintech companies have on the Romanian market, we can list the developed internet infrastructure, the encouragement of private investments by the state and the entrepreneurial spirit in development. There are also threats such as over-regulation and bureaucracy.

Table 3. Opportunities and threats

\begin{tabular}{|l|l|}
\hline Opportunities & Threats \\
\hline $\begin{array}{l}\text { Support schemes through state tax relief (for example, } \\
\text { revenue relief for IT specialists or support for setting up } \\
\text { new development centers for companies) }\end{array}$ & $\begin{array}{l}\text { Regulations both from the European institutions and } \\
\text { from national institutions }\end{array}$ \\
\hline $\begin{array}{l}\text { Romania has one of the fastest Internet connections in } \\
\text { Europe (5th place in the world on broadband internet) } \\
\text { (SpeedTest, 2019) }\end{array}$ & $\begin{array}{l}\text { Excessive bureaucracy and the need for physical } \\
\text { documents }\end{array}$ \\
\hline $\begin{array}{l}\text { Increasing public investments in the digitalization and } \\
\text { implementation of electronic payments }\end{array}$ & $\begin{array}{l}\text { Macroeconomic aspects (currency exchange rate } \\
\text { depreciation, deterioration of economy deficits) }\end{array}$ \\
\hline $\begin{array}{l}\text { Supporting young entrepreneurs and providing facilities } \\
\text { from the state }\end{array}$ & $\begin{array}{l}\text { Cheap labor force from China and India, with high } \\
\text { skill level }\end{array}$ \\
\hline Expansion of Romanian start-ups outside the borders & Influence on macroeconomic stability \\
\hline Implementation of the PSD2 directive & Frequent changes in legislation \\
\hline
\end{tabular}

Source: Authors' own research.

In Romania there are numerous opportunities for the development of fintech products. We can highlight the state support for startups through various programs financed from the state budget or from European funds, tax exemptions for employees in the IT sector in order to encourage business development. Another opportunity highlighted by the expansion of startups on international markets, products such as Pago, Volt, FintechOS becoming more and more present in Eastern European markets (Bulgaria, Serbia, Hungary, etc.) or in Western European markets or the United States. of America. State investments in the digitalization of the public sector and the integration of electronic payments will become increasingly necessary, especially in the current context of the coronavirus pandemic. Another very important aspect on which all these opportunities are based is the very good connection to the internet network, which is demonstrated by stability and speed even in the conditions of data traffic in the current period.

Regarding threats, they mainly refer to the regulations of the European or national institutions and excessive bureaucracy by presenting physical documents or a very large number 
of documents whose obtaining takes a long time. Also, macroeconomic aspects such as exchange rate stability, public debt, economic deficits influence the confidence of international partners in the Romanian economy, and frequent legislative changes prevent companies from implementing multi-year investment plans in technologies that integrate electronic payments.

\section{Discussions}

As we have noticed in the present paper, the market for fintech solutions in Romania is in a continuous growth and development, both on the segment addressed to individuals and in the segment addressed to companies. Also, we find that there are a large number of expansion possibilities for startups that appeared both in Romania and abroad, considering the technological evolution, the increasing degree of adoption of fintech solutions considering the maturation process of the market and increasing customer confidence.

Within fintech solutions we observe a large presence of emerging technologies such as artificial intelligence, machine learning or blockchain. From a technological point of view, it is to be followed the future evolution of these technologies in the market and the way in which electronic payments and fintech solutions as a whole will offer to the users new features using the emerging technologies.

From my point of view, on the fintech solutions market in Romania there is a great potential for growth in the areas of securing the confidentiality and security of the transactions, the efficiency of the foreign exchange process, the monitoring of the prices on the capital market and the forecasting of the subsequent results, open banking by offering access to financial data, digital scorecards for online and mobile lendings / insurances.

\section{Conclusions}

In conclusion, we can say that the fintech ecosystem in Romania is constantly developing. Thus, from the previous statistics it turns out that there is a market with high growth potential (only 16\% of the population uses fintech services, the services are in continuous development, PSD2 directives giving them access to the financial information of the clients). Also, agility and innovation characterize fintech companies, which have the possibility to transform the market through innovation.

As can be seen, the Romanian fintech companies are active especially in the areas of electronic payments (money transfer, payment of invoices, purchases), in the area of capital markets (robo-advisers) or personal finance management.

As for the market, there are many strengths related to the workforce, the level of taxation or the economic context, but there are also weaknesses related to demographic distribution and access to the Internet, corruption or managing one's own finances. Also, through opportunities we can list the active business environment and the good speed on the Internet, regulation on the market or digitization of state institutions. In contrast, there are a number of threats, including excessive bureaucracy, lack of financial education of the population or influences on macroeconomic stability.

Finally, we can say that technology will change the financial sector, everything will become simpler, faster, cheaper and secure, and in the near future a number of technologies such as artificial intelligence, machine learning or blockchain will impact the financial market.

Acknowledgements: This paper was co-financed from the Human Capital Operational Program 2014-2020, project number POCU / 380/6/13/125245 no. 36482 / 23.05.2019 "Excellence 
in interdisciplinary $\mathrm{PhD}$ and post-PhD research, career alternatives through entrepreneurial initiative (EXCIA)", coordinator The Bucharest University of Economic Studies.

\section{References}

Baltoi, I.-C.-M. (2019). SOCIAL NETWORKS: ADVANTAGES AND OPPORTUNITIES. Proceeding of the 18th International Conference on Informatics in Economy (pp. 241248). Bucharest: Romanian Association for Informatics in Economy.

Business Review. (2019, March 13). Business Review. Retrieved January 10, 2020, from Business Review: http://business-review.eu/tech/fintechs-to-the-rescue-how-romanianentrepreneurs-can-maximize-the-benefits-resulting-from-the-growing-presence-offintech-players-on-the-local-market-198028

DataReportal. (2019). Digital 2019 Romania. DataReportal.

Deloitte. (2017). Fintech in CEE. London: Deloitte.

Duma, F., \& Gligor, R. (2018). Study Regarding Romanian Students' Perception and Behaviour Concerning the Fintech Area with a Focus on Cryptocurrencies and Online Payments. On-line Journal Modelling the New Europe, 86-106.

Ensight. (2019). Ensight. Retrieved January 10, 2020, from Ensight: https://www.ensight.ro/caresunt-punctele-cheie-pentru-succesul-fintech-urilor/

European Banking Authority. (2017, August 4). Discussion Paper on the EBA's approach to financial technology (FinTech). Paris, France.

Eurostat. (2019). Salariile și costul forței de muncă. Bucharest: Eurostat.

Future Banking. (2020). Romanian Fintech Map. Bucharest: Future Banking.

Insider, R. (2019, February 12). Romania Insider. Retrieved January 10, 2020, from Romania Insider: https://www.romania-insider.com/16-romanian-internet-users-fintech-2019

Kavuri, A., \& Milne, A. (2019, February). FinTech and the future of financial services: What are the research gaps? Australia.

Manta, O. (2018). Financial Technologies (FinTech), Instruments, mechanisms and financial products. Bucharest, Romania.

Micu, I., \& Micu, A. (2016). Financial technology (fintech) and its implementation on the Romanian non-banking capital market. SEA - Practical Application of Science, 379-384.

Mihail, L.-G. (2018, September). Tehnologia financiară (Fintech) și implicații asupra stabilităţii financiare. Iasi, Romania.

Moraru, A.D. \& Duhnea, C. (2018). E-banking and customer satisfaction with banking services. Strategic Management, 23(3), 3-9.

Nguyen, T.A.N., \& Rozsa, Z. (2019). Financial literacy and financial advice seeking for retirement investment choice. Journal of Competitiveness, 11(1), 70-83.

Raiffeisen Bank International. (2018). CEE Fintech Atlas. Vienna: Raiffeisen Bank International. SpeedTest. (2019, November). SpeedTest Global Index. Retrieved January 10, 2020, from SpeedTest: https://www.speedtest.net/global-index/romania

Statista. (2018). Statista. Retrieved January 10, 2020, from Statista.com: https://www.statista.com/outlook/295/148/fintech/romania 